\title{
Development of hyperglycaemia and insulin resistance in conscious genetically diabetic (C57BL/KsJ-db/db) mice
}

\author{
H. Kodama, M. Fujita, I. Yamaguchi \\ Basic Research Group, Tsukuba Research Laboratories, Fujisawa Pharmaceutical Co. Ltd., Tsukuba, Ibaraki, Japan
}

Summary A bolus injection of insulin dose-dependently reduced plasma glucose levels in genetically diabetic $(\mathrm{db} / \mathrm{db})$ mice and their normoglycaemic littermates $(+I+$ mice $)$ aged 5,8 and 12 weeks. Compared between the groups, the dose-response curves showed that insulin resistance was already present in the 5week-old $\mathrm{db} / \mathrm{db}$ mice when they were still normoglycaemic. The minimum effective dose of insulin was lower in the $+/+(32 \mu \mathrm{g} / \mathrm{kg})$ than in the $\mathrm{db} / \mathrm{db}$ $(100 \mu \mathrm{g} / \mathrm{kg})$ mice and the maximum response which was obtained at $320-1000 \mu \mathrm{g} / \mathrm{kg}$ of the hormone was higher in the former (about 80\%) than in the latter (about $55 \%$ ). Although the basal plasma glucose levels in the $\mathrm{db} / \mathrm{db}$ mice were significantly increased with age as compared with those in the $+1+$ mice, the insulin response curves were identical in the $\mathrm{db} / \mathrm{db}$ mice from 5 to 12 weeks of age. The number of insulin binding sites were significantly decreased by $22-50 \%$ (5-12-weekold) in the liver plasma membrane from the $\mathrm{db} / \mathrm{db}$ mice compared with that from the $+/+$ mice, while its af- finity was not significantly changed between the groups. Streptozotocin $(100 \mathrm{mg} / \mathrm{kg}$, i.p.) treatment increased the number of insulin receptors in the $\mathrm{db} / \mathrm{db}$ mice to a number comparable with those in the $+T+$ mice. Coinciding with the change, the hypoglycaemic action of insulin was slightly enhanced in the streptozotocin-treated $\mathrm{db} / \mathrm{db}$ mice compared with that in nontreated $\mathrm{db} / \mathrm{db}$ mice, but was still considerably depressed when compared with that in $+1+$ mice. It is concluded that a simple dose-response study using a bolus injection of insulin can detect insulin resistance in $\mathrm{db} / \mathrm{db}$ mice which occurred before the manifestation of hyperglycaemia and remained constant during the course of developing hyperglycaemia. Down-regulation of insulin receptors due to the hyperinsulinaemia may play only a part in the insulin resistance. [Diabetologia (1994) 37: 739-744]

Key words $\mathrm{Db} / \mathrm{db}$ mice, insulin resistance, streptozotocin, receptor down-regulation, hyperglycaemia.
NIDDM has been characterized by hyperglycaemia, hyperinsulinaemia and decreased insulin action, and the causal relationship between these factors has long been a subject of experimental studies. Several lines of evidence $[1,2]$ suggested that hyperinsulinaemia in genetically obese ob/ob mice caused a down regulation

Received: 9 November 1993

and in revised form: 24 February 1994

Corresponding author: Dr. H. Kodama, Basic Research Group, Tsukuba Research Laboratories, Fujisawa Pharmaceutical Co. Ltd., 5-2-3 Tokodai, Tsukuba, Ibaraki 300-26, Japan

Abbreviations: STZ, Streptozotocin; NIDDM, non-insulin-dependent diabetes mellitus; $\mathrm{Kd}$, dissociation constant. of insulin receptors which in turn leads to the development of insulin resistance. Although all these changes may be involved in the pathogenesis of hyperglycaemia in ob/ob mice, a direct link between them remains to be elucidated. Previous work on ob/ob mice suggested that one or more alteration beyond the receptor downregulation plays a major role in insulin resistance of the tissues [3, 4]. In addition, a genetic analysis of diet-induced diabetic mice (C57BL/6J) by Surwit et al. [5] indicated a lack of relationship between insulin resistance and the degree of hyperglycaemia.

A genetically diabetic mouse $(\mathrm{C} 57 \mathrm{BL} / \mathrm{KsJ}-\mathrm{db} / \mathrm{db})$ has been introduced by Hummel et al. [6] as an animal model of NIDDM. Hyperglycaemia develops with age in these mice, and is preceded by hyperinsulinaemia 
[7]. Insulin resistance has also been detected in perfused hindquarter preparations of anaesthetized $\mathrm{db} / \mathrm{db}$ mice by Chan and Dehaye [8] and Chan and Tatoyan [9], who speculated that a defect in the glucose transport system might play a major role in the development of insulin resistance of the skeletal muscle. However, there have been few studies on the linkage between the insulin resistance and the age-associated development of hyperglycaemia.

The present experiment has a dual purpose. One is to detect insulin resistance in conscious $\mathrm{db} / \mathrm{db}$ mice using a more simple method, and the other is to study the insulin resistance in relation to the age-dependent development of hyperglycaemia in the mice.

\section{Materials and methods}

Characterization of age-related changes in $\mathrm{db} / \mathrm{db}$ mice. Female $\mathrm{C} 57 \mathrm{BL} / \mathrm{KsJ}-\mathrm{db} / \mathrm{db}$ mice and their normoglycaemic littermates $(+1+)$ aged 4 weeks were purchased from Jackson Laboratories (Bar Harbor, Me., USA), housed in our laboratories and fed standard mouse chow (Clea Japan, Tokyo, Japan) and tap water. The experiment was performed at the ages of 5,8 and 12 weeks.

Thirty microlitres of blood was taken from the orbital sinus of the mice using heparinized capillary tubes (Chase Instruments, Glen Falls, N.Y., USA), which was then centrifuged at $8,000 \mathrm{~g}$ for $10 \mathrm{~min}$ to obtain the plasma. The plasma concentrations of glucose were determined by the glucose-oxidase method using a commercial kit (Wako Pure Chemical, Osaka, Japan).

Blood samples were taken from the heart with the mice under ether anaesthesia, mixed with 500 units/ml of aprotinin (Boehringer Mannheim, Mannheim, Germany) and $1.2 \mathrm{mg} / \mathrm{ml}$ of EDTA - 2Na (Nakarai Tesque, Kyoto, Japan), and centrifuged at $8,000 \mathrm{~g}$ for $10 \mathrm{~min}$. Plasma insulin levels were determined using a commercial RIA kit (Kabi Pharmacia Diagnostics, Uppsala, Sweden).

The liver was immediately removed after the blood sampling and stored at $-80^{\circ} \mathrm{C}$ until used. The frozen liver was homogenized in five volumes of $50 \mathrm{mmol} / 1$ Tris (Nakarai Tesque, Kyoto, Japan)/HCl buffer solution $(\mathrm{pH} 7.4)$ containing $0.25 \mathrm{~mol} / \mathrm{l}$ sucrose and $500 \mathrm{units} / \mathrm{ml}$ of aprotinin under ice/water cooling. The homogenate was centrifuged at $12,000 \mathrm{~g}$ for $30 \mathrm{~min}$ at $4{ }^{\circ} \mathrm{C}$. The resulting supernatants were centrifuged again at $40,000 \mathrm{~g}$ for $40 \mathrm{~min}$ at $4^{\circ} \mathrm{C}$ to obtain pellets which were resuspended in $50 \mathrm{mmol} / \mathrm{l}$ Tris/ $\mathrm{HCl}$ buffer solution ( $\mathrm{pH} 7.4$ ). The suspensions (membrane samples) were stored at $-80^{\circ} \mathrm{C}$ and used for determining the specific binding capacity and affinity for insulin. The protein concentration was determined by the method of Lowry et al. [10], with bovine serum albumin (BSA, fraction V powder; Sigma, St. Louis, Mo., USA) as the standard.

Conditions for the insulin binding studies were similar to those described by Nishimura et al. [11]. The membrane samples (about $1.0 \mathrm{mg}$ protein/tube), $20 \mathrm{nCi} /$ tube of ${ }^{125} \mathrm{I}$-labelled porcine insulin (Du Pont NEN Research Products, Boston, Mass., USA) and graded amounts (0-320 ng/tube) of unlabelled bovine pancreas insulin (Sigma) were mixed in $0.4 \mathrm{ml}$ of $50 \mathrm{mmol} / 1 \mathrm{Tris} / \mathrm{HCl}$ buffer solution ( $\mathrm{pH} 7.4$ ) containing $2 \%(\mathrm{w} / \mathrm{v}) \mathrm{BSA}$ and $2 \mathrm{mg} / \mathrm{ml}$ bacitracin (Wako Pure Chemical, Osaka, Japan). After $2 \mathrm{~h}$ at $25^{\circ} \mathrm{C}$, the mixtures were centrifuged at $1,000 \mathrm{~g}$ for $30 \mathrm{~min}$. The pellets were washed with $1 \mathrm{ml}$ of the same buffer and the membrane-bound radioactivity in the pellet was measured by a gamma-ray counter (Auto-Gamma model 5650; Packard, Downers Grove, Ill., USA). The non-specific binding was deter-
Table 1. Age-related changes in body weight, plasma glucose and insulin levels in $+/+$ and $\mathrm{db} / \mathrm{db}$ mice

\begin{tabular}{ccccc}
\hline $\begin{array}{l}\text { Age } \\
\text { (weeks) }\end{array}$ & Type & $\begin{array}{l}\text { Body weight } \\
(\mathrm{g})\end{array}$ & $\begin{array}{l}\text { Plasma glucose } \\
(\mathrm{mmol} / \mathrm{l})\end{array}$ & $\begin{array}{l}\text { Plasma insulin } \\
(\mathrm{pmol} / \mathrm{l})\end{array}$ \\
\hline 5 & $+/+$ & $17.5 \pm 0.3$ & $9.2 \pm 0.3$ & $59 \pm 2$ \\
5 & $\mathrm{db} / \mathrm{db}$ & $24.2 \pm 0.8^{\mathrm{a}}$ & $10.0 \pm 0.5$ & $871 \pm 65^{\mathrm{a}}$ \\
8 & $+/+$ & $21.1 \pm 0.6$ & $10.3 \pm 0.2$ & $62 \pm 5$ \\
8 & $\mathrm{db} / \mathrm{db}$ & $39.5 \pm 0.7^{\mathrm{a}}$ & $26.6 \pm 1.2^{\mathrm{a}}$ & $521 \pm 79^{\mathrm{a}}$ \\
12 & $+/+$ & $27.8 \pm 0.5$ & $9.6 \pm 0.1$ & $46 \pm 5$ \\
12 & $\mathrm{db} / \mathrm{db}$ & $50.5 \pm 1.7^{\mathrm{a}}$ & $34.7 \pm 1.7^{\mathrm{a}}$ & $163 \pm 16^{\mathrm{a}}$ \\
\hline
\end{tabular}

Values are presented as mean \pm SEM of eight mice. ${ }^{a} p<0.001$ vs $+/+$ mice at the same age

mined in the presence of an excess of unlabelled hormone $(2 \mu \mathrm{g} /$ tube). Binding capacity and affinity for insulin was estimated by Scatchard analysis of the dose-response data.

STZ treatment. STZ (Sigma) was freshly dissolved in $2 \mathrm{mmol} / 1 \mathrm{ci}-$ tric acid/NaOH buffer solution ( $\mathrm{pH} 4.5$ ) with $154 \mathrm{mmol} / \mathrm{l} \mathrm{NaCl}$, and injected intraperitoneally to $+1+$ and $\mathrm{db} / \mathrm{db}$ mice at a dose of $150 \mathrm{mg} / \mathrm{kg}$ and $100 \mathrm{mg} / \mathrm{kg}$, respectively. The doses were selected because the $\mathrm{db} / \mathrm{db}$ mice were more prone to the toxicity of STZ than $+1+$ mice. Three weeks after the injection, the 8week-old mice were used for the time-course as well as the doseresponse studies on insulin action described below. They were also provided for the assays described above.

Hypoglycaemic activity of insulin. Time-course study: eightweek-old $+1+$ and $\mathrm{db} / \mathrm{db}$ mice treated with or without STZ were given a subcutaneous injection $(100 \mu \mathrm{g} / \mathrm{kg})$ of bovine pancreas insulin (Sigma) dissolved in $1 \mathrm{mmol} / 1 \mathrm{HCl}$ solution with $154 \mathrm{mmol} / \mathrm{l} \mathrm{NaCl}$. Chow was removed soon after the injection, and $30 \mu \mathrm{l}$ of blood was taken from the orbital sinus at 0 (before), $20,40,60$ and $120 \mathrm{~min}$ thereafter and used for determining plasma glucose levels. In a separate experiment to determine timecourse changes in circulating insulin levels after insulin injection, $50 \mu \mathrm{l}$ of blood was taken at $0,10,20$ and $40 \mathrm{~min}$ after the injection of insulin $(100 \mu \mathrm{g} / \mathrm{kg}$, s.c.). Plasma glucose and insulin levels were assayed as described above.

Dose-response study: the above-mentioned time-course study revealed that the blood glucose response reached its maximum 40 min after the injection of insulin. Thus, $30 \mu \mathrm{l}$ of blood was taken from the orbital sinus of the $+1+$ and $\mathrm{db} / \mathrm{db}$ mice treated with or without STZ 40 min after s. c. doses of insulin $(0,1,3.2,10$, $32,100,320$ and $1000 \mu \mathrm{g} / \mathrm{kg}$ ) and served for plasma glucose determinations. The blood glucose levels of the insulin dosing group were expressed as percent of that of the control group (insulin; 0 ).

\section{Statistical analysis}

All values were given as the mean $\pm S E M$. Significance of differences between means was assessed using the Student's $t$-test.

\section{Results}

Body weight and plasma parameters in $+/+$ and $d b / d b$ mice. The characteristics of $+1+$ and $\mathrm{db} / \mathrm{db}$ mice aged 5,8 and 12 weeks are compared in Table 1 . At 5 weeks of age, the body weight of the $\mathrm{db} / \mathrm{db}$ mice was approximately 1.4 times that of the $+1+$ mice, and the difference between the two increased with age. At 
Table 2. Age-related changes in hepatic insulin binding capacity and affinity in $+1+$ and db/db mice

\begin{tabular}{|c|c|c|c|c|c|}
\hline \multirow{2}{*}{$\begin{array}{l}\text { Age } \\
\text { (weeks) }\end{array}$} & \multirow[t]{2}{*}{ Type } & \multicolumn{2}{|l|}{ High affinity } & \multicolumn{2}{|l|}{ Low affinity } \\
\hline & & $\begin{array}{l}\text { Binding capacity } \\
\text { (fmol/mg protein) }\end{array}$ & $\mathrm{K}_{\mathrm{d}}(\mathrm{nmol} / \mathrm{l})$ & $\begin{array}{l}\text { Binding capacity } \\
\text { (fmol/mg protein) }\end{array}$ & $\mathrm{K}_{\mathrm{d}}(\mathrm{nmol} / \mathrm{l})$ \\
\hline 5 & $\mathrm{db} / \mathrm{db}$ & $161 \pm 26^{a}$ & $1.2 \pm 0.1$ & $257 \pm 39^{a}$ & $3.9 \pm 0.9$ \\
\hline 8 & $+1+$ & $369 \pm 26$ & $0.8 \pm 0.04$ & $601 \pm 48$ & $2.2 \pm 0.4$ \\
\hline 8 & $\mathrm{db} / \mathrm{db}$ & $190 \pm 14^{b}$ & $0.8 \pm 0.1$ & $318 \pm 19^{b}$ & $1.9 \pm 0.1$ \\
\hline
\end{tabular}

Values are presented as mean \pm SEM of eight mice. ${ }^{a} p<0.05,{ }^{b} p<0.001 \mathrm{vs}+1+$ mice at the same age

5 weeks, plasma glucose levels were not different between the $\mathrm{db} / \mathrm{db}$ and $+1+$ mice, and then significantly increased in the former (5-week-old $\mathrm{db} / \mathrm{db}$ vs 8 -week-old or 12 -week-old $\mathrm{db} / \mathrm{db}, p<0.001$ ), but remained constant in the latter. The differences between the two increased with age. The plasma insulin levels of the $\mathrm{db} / \mathrm{db}$ mice peaked at 5 weeks, then decreased agedependently, whereas those of the $+1+$ mice remained constant. The differences between the two were statistically significant at all ages, but decreased with age.

Insulin receptors in $+/+$ and $d b / d b$ mice. A Scatchard plot of displaced ${ }^{125}$ I-insulin by insulin was linear at the lower and higher concentrations of the latter, revealing high and low affinity binding sites in the mouse membrane samples from the liver (data not shown). Insulin binding, either of high or low affinity, was almost halved in the membrane preparations from 5-week-old $\mathrm{db} / \mathrm{db}$ compared with $+l+$ mice (Table 2 ). Thereafter, the binding increased with age in both groups. However, the degree of change was greater in the $\mathrm{db} / \mathrm{db}$ than in $+1+$ mice, and the difference between the two de-

Table 3. Effect of STZ on body weight, plasma glucose and insulin levels in $+/+$ and $\mathrm{db} / \mathrm{db}$ mice

\begin{tabular}{llcc}
\hline Type & $\begin{array}{l}\text { Body weight } \\
(\mathrm{g})\end{array}$ & $\begin{array}{l}\text { Plasma glucose } \\
(\mathrm{mmol} / \mathrm{l})\end{array}$ & $\begin{array}{l}\text { Plasma insulin } \\
(\mathrm{pmol} / \mathrm{l})\end{array}$ \\
\hline$+/+$ & $22.6 \pm 0.6$ & $9.9 \pm 0.2$ & $59 \pm 5$ \\
STZ- $+/+$ & $16.4 \pm 0.6^{\mathrm{a}}$ & $38.2 \pm 0.8^{\mathrm{a}}$ & $25 \pm 4^{\mathrm{a}}$ \\
$\mathrm{db} / \mathrm{db}$ & $39.9 \pm 0.7^{\mathrm{a}}$ & $25.0 \pm 1.0^{\mathrm{a}}$ & $439 \pm 49^{\mathrm{a}}$ \\
STZ-db/db & $22.2 \pm 1.1^{\mathrm{b}}$ & $37.1 \pm 1.3^{\mathrm{b}}$ & $62 \pm 9^{\mathrm{b}}$ \\
\hline
\end{tabular}

Values are presented as mean \pm SEM of eight mice. a $p<0.001$ vs $+1+,{ }^{b} p<0.001$ vs db/db mice creased with age. The $\mathbf{K}_{d}$ values did not significantly differ between $+1+$ and $\mathrm{db} / \mathrm{db}$ mice, though they tended to be lower in the latter.

Body weight and plasma parameters after STZ treatment. As shown in Table 3, STZ treatment significantly reduced body weight and plasma insulin levels, and increased plasma glucose levels in the $+1+$ as well as in the $\mathrm{db} / \mathrm{db}$ mice. The STZ treated $\mathrm{db} / \mathrm{db}$ mice showed $44 \%$ reduction of body weight, and were approximately the same weight as the $+1+$ mice. A similar but slightly lower reduction of body weight ( $27 \%$ ) was observed in the $+1+$ mice after STZ treatment. The increase in plasma glucose induced by STZ treatment was greater in the $+1+(286 \%)$ than in the $\mathrm{db} / \mathrm{db}$ (48\%) mice, and the plasma glucose level was approximately equal between the $+1+$ and $\mathrm{db} / \mathrm{db}$ mice after treatment. Plasma insulin levels decreased by $58 \%$ in the $+1+$ mice, and by $86 \%$ in the $\mathrm{db} / \mathrm{db}$ mice after STZ treatment, which in the STZ treated $\mathrm{db} / \mathrm{db}$ mice was approximately equal to that in the intact $+1+$ mice.

Insulin receptors after $S T Z$ treatment. STZ treatment in the $+/+$ mice hardly affected the number and $K_{d}$ value of insulin receptors, either of high or low affinity (Table 4). In contrast, both the number and $\mathrm{K}_{\mathrm{d}}$ values of the receptors increased in the $\mathrm{db} / \mathrm{db}$ mice after STZ treatment, becoming almost equal to those in the intact $+/+$ mice.

Hypoglycaemic action in $+/+$ and $d b / d b$ mice treated with or without $S T Z$. Figure 1 shows the time-course changes in plasma glucose levels after the injection of insulin $(100 \mu \mathrm{g} / \mathrm{kg}, \mathrm{s} . \mathrm{c}$. $)$ in the 8 -week-old $+l+$ and

Table 4. Changes in hepatic insulin binding capacity and affinity in $+1+$ and db/db mice with or without STZ treatment

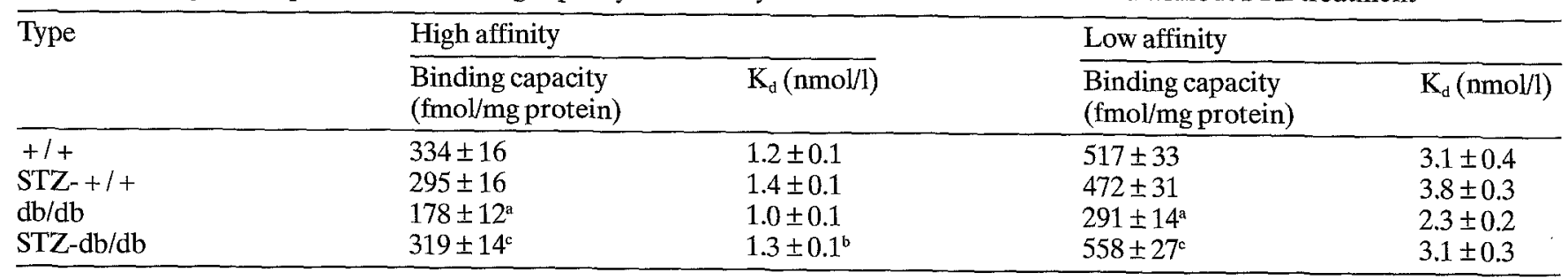

Values are presented as mean \pm SEM of eight mice. ${ }^{a} p<0.001 \mathrm{vs}+1+$ mice; ${ }^{b} p<0.05,{ }^{c} p<0.001 \mathrm{vs} \mathrm{db} / \mathrm{db}$ mice 


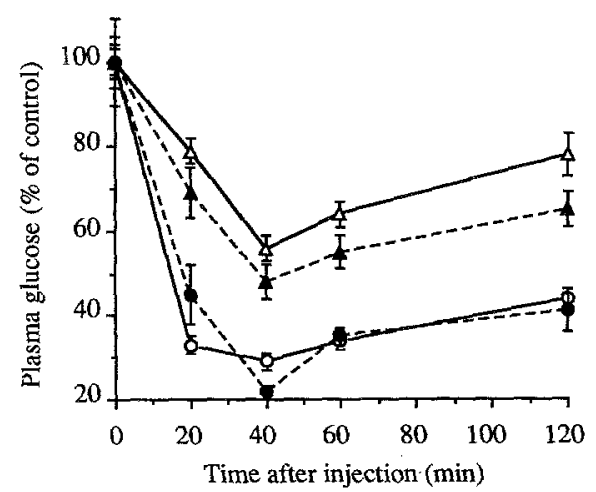

Fig. 1. Time-course change in plasma glucose levels after insulin injection in normal and diabetic mice. $-\mathrm{O}-,+1+$ mice; --- -, STZ treated $+/+$ mice;- $\triangle-$, db/db mice;---A---, STZ treated $\mathrm{db} / \mathrm{db}$ mice. Values are presented as percent of respective controls (mean $\pm \mathrm{SEM}, n=8$ )

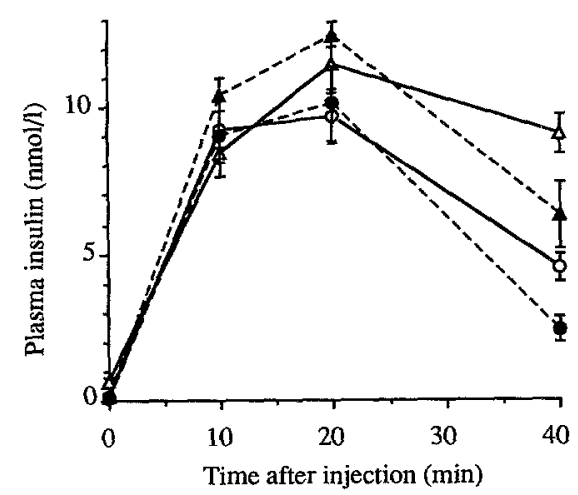

Fig. 2. Time-course change in plasma insulin levels after insulin injection in normal and diabetic mice. - $-1+$ mice; ----, STZ treated $+1+$ mice; $-\triangle-$, db/db mice; ---A---, STZ treated $\mathrm{db} / \mathrm{db}$ mice (mean $\pm \mathrm{SEM}, n=8$ )

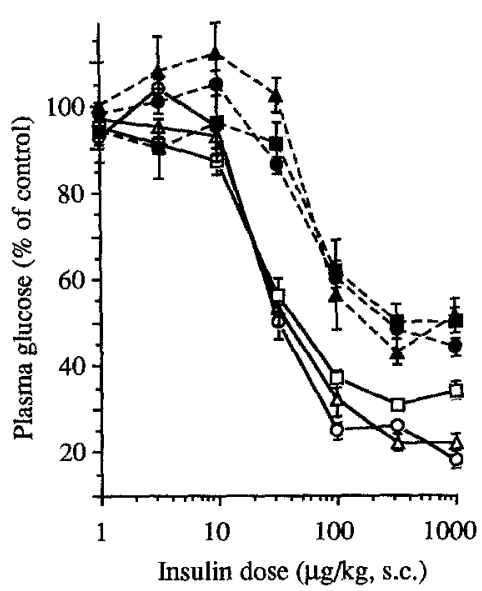

Fig. 3. Effect of insulin on plasma glucose levels in $+1+$ and $\mathrm{db} / \mathrm{db}$ mice aged 5,8 and 12 weeks. - - - 5-week-old $+1+$ mice; -- -- , 5-week-old db/db mice; $-\triangle-$, 8-weekold $+/+$ mice; ---A---, 8-week-old $\mathrm{db} / \mathrm{db}$ mice; $-\square-$, 12week-old $+/+$ mice; - -,-- 12-week-old $\mathrm{db} / \mathrm{db}$ mice. Values are presented as percent of respective controls (mean $\pm S E M$, $n=8$ ) $\mathrm{db} / \mathrm{db}$ mice treated with or without STZ. Although the dose of insulin exerted significantly greater effect in the $+/+$ mice than in the $\mathrm{db} / \mathrm{db}$ mice $(+/+\mathrm{vs} \mathrm{db} / \mathrm{db}$ at all time-intervals, $p<0.001$ ), the dynamics were similar between the groups, and the maximum hypoglycaemic action was observed at $40 \mathrm{~min}$ after the injection. The time-course change of plasma glucose levels hardly differed between the non-treated and STZ-treated $+1+$ mice and showed maximum decreases at $40 \mathrm{~min}$ after the injection. Although the time-course change was similar between the STZ-treated and non-treated $\mathrm{db} / \mathrm{db}$ mice, the response to insulin was greater in the former at all time-intervals.

After the injection of insulin $(100 \mu \mathrm{g} / \mathrm{kg}, \mathrm{s.c}$. $)$ to the 8 -week-old $+i+$ and $\mathrm{db} / \mathrm{db}$ mice treated with or without STZ, the plasma insulin levels peaked at $20 \mathrm{~min}$ and then decreased thereafter in the all groups (Fig.2). Similar circulating insulin levels were observed at 10 and $20 \mathrm{~min}$ in the $\mathrm{db} / \mathrm{db}$ and $+1+$ mice, but the levels at $40 \mathrm{~min}$ in the former were significantly higher than those in the latter $(\mathrm{db} / \mathrm{db}$ vs $+1+; 9.1 \pm 0.6$ vs $4.5 \pm 0.5 \mathrm{nmol} / 1, \quad p<0.001)$. Compared with nontreated mice, STZ treatment hardly affected the plasma insulin levels at 10 and $20 \mathrm{~min}$ in the $+1+$ or the $\mathrm{db} / \mathrm{db}$ mice, but the levels at 40 min tended to decrease with STZ in both the groups. The insulin levels at $40 \mathrm{~min}$ in plasma obtained from the mice injected with only vehicle $(1 \mathrm{mmol} / \mathrm{HCl}$ solution with $154 \mathrm{mmol} / \mathrm{l}$ $\mathrm{NaCl}$ ) were $0.09 \pm 0.02,0.77 \pm 0.14,0.04 \pm 0.01$ and $0.13 \pm 0.02 \mathrm{nmol} / \mathrm{l}$ in $+/+, \mathrm{db} / \mathrm{db}$, STZ-treated $+/+$ and STZ-treated $\mathrm{db} / \mathrm{db}$ mice, respectively.

The insulin dose-response curves were compared between the $+/+$ and $\mathrm{db} / \mathrm{db}$ mice aged 5,8 and 12 weeks (Fig. 3). Insulin (1-1000 $\mu \mathrm{g} / \mathrm{kg}$ ) dose-dependently decreased the plasma glucose levels in both the groups. The dose-response curve in the 5-week-old $\mathrm{db} / \mathrm{db}$ mice apparently shifted to the right compared to that in the $+1+$ mice at the same age. The minimum effective doses were 32 and $100 \mu \mathrm{g} / \mathrm{kg}$ in the $+/+$ and $\mathrm{db} / \mathrm{db}$ mice, respectively. In addition, the maximum hypoglycaemic responses which were obtained with $1000 \mu \mathrm{g} / \mathrm{kg}$ of insulin were greater in the $+1+$ $(82 \pm 2 \%$, decrease $)$ than in the $\mathrm{db} / \mathrm{db}(56 \pm 2 \%$, decrease) mice. Though basal plasma glucose levels progressively increased with age in the $\mathrm{db} / \mathrm{db}$ mice (8week-old, $26.6 \pm 1.2 ; 12$-week-old, $34.7 \pm 1.7 \mathrm{mmol} / \mathrm{l}$ ), the dose-response curves were almost identical irrespective of their ages. The same was true for the $+1+$ mice. The insulin dose-response curves in the $+1+$ mice were similar with or without STZ treatment (Fig.4). STZ treatment in the $\mathrm{db} / \mathrm{db}$ mice increased the response to insulin doses without changing the minimum and maximum effective doses. 


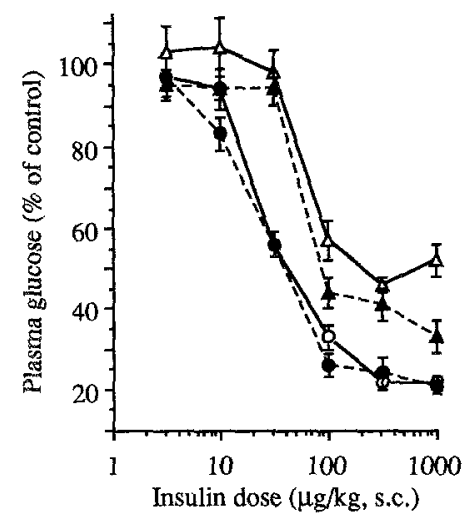

Fig.4. Effect of insulin on plasma glucose levels in $+/+$ and $\mathrm{db} / \mathrm{db}$ mice with or without STZ treatment. - $\mathrm{O}-,+1+$ mice; --- , STZ treated $+1+$ mice; $-\triangle-$, db/db mice; $-\cdots-\Delta---$, STZ treated $\mathrm{db} / \mathrm{db}$ mice. Values are presented as percent of respective controls (mean $\pm \mathrm{SEM}, n=16$ )

\section{Discussion}

In vitro studies have shown that insulin action is depressed in the skeletal muscle and liver of $\mathrm{db} / \mathrm{db}$ mice $[8,9,12]$. Extending the previous results, we detected insulin resistance in conscious $\mathrm{db} / \mathrm{db}$ mice using simple determination of plasma glucose levels after a subcutaneous injection of insulin at various doses. In order to address the possibility that the low effectiveness of insulin in $\mathrm{db} / \mathrm{db}$ mice may be due to its low absorption rate, we measured plasma insulin levels in $\mathrm{db} / \mathrm{db}$ and $+1+$ mice after the injection. Although plasma insulin levels at $40 \mathrm{~min}$ after the injection were slightly higher in $\mathrm{db} / \mathrm{db}$ mice than $+1+$ mice, similar plasma insulin levels were observed at 10 and $20 \mathrm{~min}$ after the injection of insulin $(100 \mu \mathrm{g} / \mathrm{kg}$, s. c. $)$ in both the groups. This indicates that the absorption rate of s.c. injected insulin was not lower in $\mathrm{db} / \mathrm{db}$ mice than that in $+1+$ mice, excluding the previously mentioned possibility.

The minimum effective dose of insulin on plasmaglucose levels was higher in the 5 -week-old db/db mice than in the $+1+$ mice, and the maximum response was lower in the former. The difference in the dose-response curves can hardly be attributed to the basal plasma glucose levels because the levels were not significantly different between the two at the same age. According to Chan and Dehaye [8] and Chan and Tatoyan [9] basal glucose uptake in the perfused hindquarters of 5-weekold db/db mice was depressed when compared with that of $+1+$ mice at the same age. However, they also showed that the glucose uptake was increased to a similar level with $1000 \mu \mathrm{U} / \mathrm{ml}$ of insulin in the $\mathrm{db} / \mathrm{db}$ mice and by $10 \mu \mathrm{U} / \mathrm{ml}$ of insulin in the $+1+$ mice. Slightly lower but comparable basal plasma insulin levels were obtained in the present experiment $(871 \mathrm{pmol} / 1$ in the $\mathrm{db} / \mathrm{db}$ mice and $59 \mathrm{pmol} / \mathrm{lin}$ the $+1+$ mice, at 5 weeks of age). It is thus reasonable to assume that glucose uptake by the skeletal muscle may be similar between the 5 week-old $\mathrm{db} / \mathrm{db}$ and $+1+$ mice being compensated for in the former by hyperinsulinaemia. Insulin resistance, although it exists in the young pre-diabetic $\mathrm{db} / \mathrm{db}$ mice, appears to be compensated for by the hyperinsulinaemia.

Decreased sensitivity and maximum responses to exogenous insulin were also found in the 8 and 12week-old $\mathrm{db} / \mathrm{db}$ mice, when they developed significant hyperglycaemia. This change in insulin dose-response curve was not due to the difference in basal plasma glucose levels between the $\mathrm{db} / \mathrm{db}$ and $+1+$ mice, since STZ treatment of the $+1+$ mice increased basal plasma glucose levels but hardly affected the insulin doseresponse curve. On the other hand, when different ages of $\mathrm{db} / \mathrm{db}$ mice were compared, the insulin dose-response curves were almost the same both before and after the manifestation of hyperglycaemia, and scarcely any unidirectional change was observed despite the age-dependent increase in basal plasma glucose levels in the 5-12-week-old $\mathrm{db} / \mathrm{db}$ mice. These results support the view that insulin resistance per se may not be directly involved in the age-associated development of hyperglycaemia. This is in accordance with the genetic analysis in diet-induced diabetic C57BL/6J mice by Surwit et al. [5] who indicated that insulin resistance and hyperglycaemia are controlled by different genetic factors. On the other hand, it has been reported that plasma glucagon levels and hepatic gluconeogenic enzyme activity increases with age in $\mathrm{db} / \mathrm{db}$ mice [1315], suggesting an important role for hepatic glucose production in the age-related development of hyperglycaemia in $\mathrm{db} / \mathrm{db}$ mice.

The present ${ }^{125} \mathrm{I}$-insulin binding study to liver plasma membranes revealed that the number, not the affinity, of insulin receptors decreased in the $\mathrm{db} / \mathrm{db}$ mice compared with the $+/+$ mice at all ages. The difference between the mice paralleled that of the plasma insulin levels, peaking at 8 weeks of age. In addition, STZ treatment to the $\mathrm{db} / \mathrm{db}$ mice completely abolished the hyperinsulinaemia and increased the receptor number to the level of the $+1+$ mice. These results parallel those in obese hyperinsulinaemic animals such as ob/ob mice [3, 4] and Zucker (fa/fa) rats [16, 17], suggesting that hyperinsulinaemia causes a down-regulation of insulin receptor in the liver and peripheral tissues. In fact, it has been reported that in vitro exposure to insulin decreased the number but not the affinity of insulin receptors in cultured human lymphocytes $[18$, 19] and rat hepatocytes [20]. The liver has a relatively high level of insulin binding capacity, and activation of the receptors by insulin suppresses the glucose production rate and potentiates glycogen synthesis which might contribute to its hypoglycaemic action. It is thus possible that the down-regulation of hepatic insulin receptors is involved in the insulin resistance of $d b / d b$ mice. However, the insulin action in $\mathrm{db} / \mathrm{db}$ mice determined in the present study was only partially enhanced after STZ treatment, and there was still a considerable difference in the action between the STZ-treated db/db 
and the $+1+$ mice. These results indicate that factors other than hepatic insulin receptor deficiency may play a major role in the insulin resistance of $\mathrm{db} / \mathrm{db}$ mice. Le Marchand et al. [3] also reported an increase in insulin binding following prolonged fasting or STZ treatment in association with enhanced insulin-stimulated glucose metabolism in the isolated soleus muscle but not in the perfused liver of ob/ob mice, indicating that the relationship between insulin binding and its metabolic action is not identical in all tissues.

In conclusion, the simple insulin dose-response study in conscious $\mathrm{db} / \mathrm{db}$ mice clearly demonstrated insulin resistance in the mice. The insulin resistance occurred before the manifestation of hyperglycaemia, and remained constant despite the development of hyperglycaemia. Insulin receptor deficiency due to receptor down-regulation can only explain a part, not all, of the insulin resistance in $\mathrm{db} / \mathrm{db}$ mice.

Acknowledgement. We thank Dr. T. Ohashi for helpful advice in preparing the manuscripts.

\section{References}

1. Kahn CR, Neville DM Jr, Roth J (1973) Insulin-receptor interaction in the obese-hyperglycemic mouse. A model of insulin resistance. J Biol Chem 248: 244-250

2. Forgue ME, Freychet $\mathbf{P}$ (1975) Insulin receptors in the heart muscle. Demonstration of specific binding sites and impairment of insulin binding in the plasma membrane of the obese hyperglycemic mouse. Diabetes 24: 715-723

3. Le Marchand Y, Loten EG, Assimacopoulos-Jeannet F, Fórgue ME, Freychet P, Jeanrenaud B (1977) Effect of fasting and streptozotocin in the obese-hyperglycemic (ob/ob) mouse. Apparent lack of a direct relationship between insulin binding and insulin effects. Diabetes 26: 582-590

4. Le Marchand-Brustel Y, Jeanrenaud B, Freychet P (1978) Insulin binding and effects in isolated soleus muscle of lean and obese mice. Am J Physiol 234: E348-E358

5. Surwit RS, Seldin MF, Kuhn CM, Cochrane C, Feinglos MN (1991) Control of expression of insulin resistance and hyperglycemia by different genetic factors in diabetic C57BL/6J mice. Diabetes 40: 82-87
6. Hummel KP, Dickie MM, Coleman DL (1966) Diabetes, a new mutation in the mouse. Science 153: 1127-1128

7. Herberg L, Coleman DL (1977) Laboratory animals exhibiting obesity and diabetes syndromes. Metabolism 26: 59-99

8. Chan TM, Dehaye JP (1981) Hormone regulation of glucose metabolism in the genetically obese-diabetic mouse ( $\mathrm{db} / \mathrm{db})$. Glucose metabolism in the perfused hindquarters of lean and obese mice. Diabetes 30: 211-218

9. Chan TM, Tatoyan A (1984) Glucose transport and metabolism in the perfused hindquarters of lean and obese-hyperglycemic (db/db) mice. Biochim Biophys Acta 798: 325-332

10. Lowry OH, Rosenbrough NJ, Farr AL, Randall RJ (1951) Protein measurernent with the Folin phenol reagent. J Biol Chem 193: 265-275

11. Nishimura H, Kuzuya H, Okamoto M et al. (1988) Change of insulin action with aging in conscious rats determined by euglycemic clamp. Am J Physiol 254: E92-E98

12. Chan TM, Exton JH (1975) Glucose metabolism and insulin sensitivity in livers of genetically diabetic $(\mathrm{db} / \mathrm{db})$ mice. Fed Proc 34: 334

13. Roesler WJ, Khandelwal RL (1985) Age-related changes in hepatic glycogen metabolism in the genetically diabetic (db/db) mouse. Diabetes 34: 395-402

14. Chan TM, Young KM, Hutson NJ, Brumley FT, Exton JH (1975) Hepatic metabolism of genetically diabetic (db/db) mice. I. Carbohydrate metabolism. Am J Physiol 229: 17021712

15. Chang AY, Schneider DI (1970) Abnormalities in hepatic enzyme activities during development of diabetes in $\mathrm{db}$ mice. Diabetologia 6: 274-278

16. Clark JB, Keen S, Clark CM Jr (1982) Studies on the regulation of insulin binding by liver plasma membranes from Zucker fatty rats. Diabetes 31: 867-873

17. Slieker LJ, Roberts EF, Shaw WN, Johnson WT (1990) Effect of streptozotocin-induced diabetes on insulin-receptor tyrosine kinase activity in obese Zucker rats. Diabetes 39: 619-625

18. Gavin JR III, Roth J, Neville DM Jr, Meyts PD, Buell DN (1974) Insulin-dependent regulation of insulin receptor concentrations: a direct demonstration in cell culture. Proc Nat Acad Sci USA 71: 84-88

19. Kosmakos FC, Roth J (1980) Insulin-induced loss of the insulin receptor in IM-9 lymphocytes. J Biol Chem 255: 9860 9869

20. Lipson KE, Kolhatkar AA, Donner DB (1988) Cell surface proteolysis and down-regulation of the hepaticinsulin receptor. J Biol Chem 263: 10 495-10501 